\title{
Regaining venous access for implantation of a new lead
}

\author{
Odzyskanie dostępu żylnego do implantacji nowych elektrod endokawitarnych
}

\section{Krzysztof Kuśmierski', Paweł Syska², Aleksander Maciąg², Artur Oręziak², Mariusz Kuśmierczyk¹, Andrzej Przybylski ${ }^{1}$}

1Department of Cardiosurgery and Transplantology, Institute of Cardiology, Warsaw, Poland

22 $2^{\text {nd }}$ Department of Ischeamic Heart Disease, Institute of Cardiology, Warsaw, Poland

3Department of Cardiac Arrhythmias, Institute of Cardiology, Warsaw, Poland

\begin{abstract}
Introduction: Venous occlusion is a relatively common complication of endocardial lead implantation. It may cause a critical problem when implantation of a new lead is needed. Traditional methods result in leaving abandoned leads. The optimal approach seems to be the extraction of the damaged or abandoned lead, regaining venous access and implantation of a new lead.

Aim: To assess the efficacy and safety of new lead implantation by the method of lead extraction.

Material and methods: All transvenous lead extraction procedures (203 patients) between 1 August 2008 and 15 October 2012 were assessed. The analysis included cases with leads implanted for at least 6 months prior to extraction.

Results: Regaining venous access was the main indication for lead extraction in 5 patients (4.9\%). The reason for new lead implantation was lead damage $(n=7)$ and system up-grade to cardiac resynchronization therapy (CRT) $(n=3)$. In total, 23 leads were extracted ( 9 defibrillation leads, 12 pacing leads and 2 left ventricular leads). The mean time from the implantation was $92.2 \pm 43.2$ (48-152) months. In all cases Cook mechanical sheaths were applied. The use of the Evolution system was necessary to extract 3 leads. In all cases the new leads were successfully implanted as planned. No serious complications occurred.

Conclusions: Diagnosis of venous occlusion should not be a contraindication for ipsilateral implantation of the new lead, because the techniques of transvenous lead extraction enable successful regaining of venous access.
\end{abstract}

Key words: lead extraction, lead reimplantation.

\section{Streszczenie}

Wstęp: Niedrożność żylna jest stosunkowo częstym powikłaniem implantacji elektrod endokawitarnych. Zazwyczaj przebiega ona bezobjawowo, lecz jest istotnym problem w sytuacjach, gdy zachodzi konieczność wszczepienia nowej elektrody. Tradycyjnie stosowane metody postępowania (wszczepienie nowego układu lub nowej elektrody po przeciwnej stronie i jej tunelizacja do loży urządzenia) wiążą się z pozostawieniem nieczynnych elektrod. Wydaje się, że optymalnym sposobem postępowania jest usunięcie uszkodzonej lub zbędnej elektrody, odzyskanie dostępu do układu żylnego i wszczepienie nowej elektrody.

Cel: Ocena skuteczności i bezpieczeństwa implantacji nowej elektrody za pomocą techniki polegającej na usunięciu elektrody i odzyskiwaniu dostępu żylnego.

Materiat i metody: Analizie poddano wszystkie zabiegi usunięcia elektrod przezżylnych techniką przezżylną od 1 sierpnia 2008 do 15 października 2012 roku. Zabiegi wykonano u 203 chorych. Uwzględniono jedynie zabiegi usunięcia elektrod implantowanych $\geq 6$ miesięcy wcześniej.

Wyniki: W badanej grupie odzyskanie dostępu żylnego było głównym wskazaniem do ekstrakcji elektrody u 10 pacjentów (4,9\%). Konieczność wszczepienia nowej elektrody wynikała z uszkodzenia poprzedniej $(n=7)$ oraz rozbudowy układu do terapii resynchronizującej $(n=3)$. W czasie zabiegów usunięto 23 elektrody (9 defibrylacyjnych, 12 stymulacyjnych i 2 lewokomorowe). Średni czas od ich implantacji wynosit 92,2 $\pm 43,2$ miesiąca (zakres: 48-152 miesięcy). W każdym przypadku stosowano zestaw koszulek firmy COOK. Systemu Evolution użyto do ekstrakcji 3 elektrod. We wszystkich przypadkach udało się implantować nowe elektrody zgodnie z planowanym celem zabiegu. W analizowanej grupie nie wystąpiły poważne powikłania.

Wnioski: Stwierdzenie niedrożności żylnej nie powinno być przeciwwskazaniem do implantacji nowych elektrod po stronie poprzednio wszczepionego urządzenia, ponieważ techniki przezżylnego usunięcia elektrod umożliwiają odzyskanie dostępu do układu żylnego.

Słowa kluczowe: usuwanie elektrod endokawitarnych, doszczepianie elektrod.

\section{Corresponding author/Adres do korespondencji:}

Krzysztof Kuśmierski MD, PhD, Department of Cardiosurgery and Transplantology, Institute of Cardiology, 42 Alpejska St, 04-628 Warsaw, Poland, tel.: +48 725993 822, fax: +48 2234345 48, e-mail: K_Kusmierski@poczta.onet.pl

Received: 31.10 .2012 , accepted: 14.01.2013. 


\section{Introduction}

Significant symptoms of venous occlusion or thrombosis in patients with a pacemaker or implantable cardioverter-defibrillator (ICD) are rarely observed in clinical practice. Most frequently, the diagnosis of occlusion is made accidently or during another procedure related to the implanted device, despite the fact that venous occlusion or its significant stenosis occurs in $10-25 \%$ of patients and clinical symptoms are present in 1-3\% of cases [1, 2]. Prolongation of life and natural disease progression (especially the onset of heart failure) create a necessity to upgrade the existing pacemaker to an ICD or pacemaker/ICD with possibility of resynchronization (cardiac resynchronization therapy - CRT). In these situations it is necessary to insert a new electrode. Unfortunately, damage to the previously implanted electrode is becoming a more common indication for the procedure. Introduction of a new electrode into the venous system may be difficult due to venous occlusion (Figures 1 and 2). In that case of implantation ipsilateral to the previous one the following management strategies are possible:

1. Contralateral implantation of a new device (Figure 3).

2. Contralateral implantation of a new electrode and its percutaneous tunnelization to the previously created pacemaker implantation site (Figure 4).

3. Removal of a damaged or unnecessary lead and restoration of venous access.

The techniques listed in points 1 and 2 are subject to great inconvenience and potential risk of late complications resulting

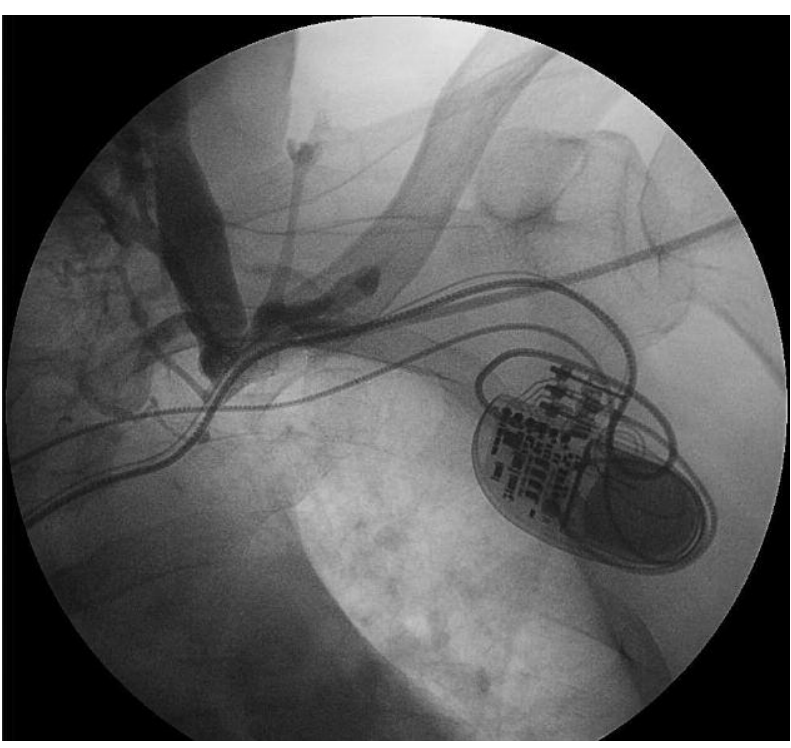

Fig. 1. Subclavian vein occlusion after previous implantation of the CRT-P - venography after introduction of the vascular sheath

Ryc. 1. Niedrożność żyły podobojczykowej po implantacji układu CRT-P przed laty - wenografia po wprowadzeniu koszulki naczyniowej from the interaction between two implanted electronic devices, excess of remaining electrodes in the venous system and the need for creation of a percutaneous passage of electrodes. Therefore, the optimal procedure seems to consist of removal of the unnecessary electrode by means of special sets and, obtained this way, restoration of venous access.

\section{Aim}

The aim of the study was to assess the efficacy and safety of a new electrode implantation technique consisting of electrode removal and restoration of venous access.

\section{Material and methods}

The analysis included procedures of endocavitary electrode removal by means of transvenous technique performed between 1.08.2008 and 15.10.2012. Only the removal procedures for electrodes implanted $\geq 6$ months earlier were chosen. Of the database including 203 patients, only procedures in which the main indication for removal was the need for implantation of a new electrode in spite of an existing ipsilateral venous occlusion were taken into consideration.

\section{Procedure description}

The procedures were performed in the operating theatre (and from January 2012 in a hybrid catheterization laboratory) with a possibility of immediate sternotomy and surgery with the use of extracorporeal circulation. Intratracheal general anaesthesia was used. There was continuous ECG, blood pres-

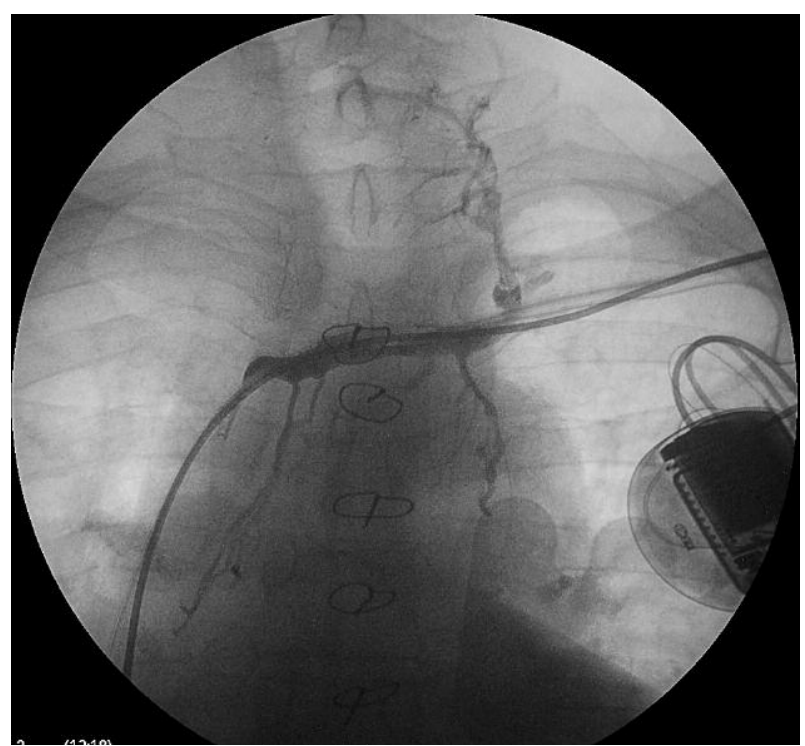

Fig. 2. Subclavian vein occlusion after ICD-DR implantation - venography after introduction of the vascular sheath

Ryc. 2. Niedrożność żyły podobojczykowej po implantacji uktadu ICD-DR - wenografia po wprowadzeniu koszulki naczyniowej 
sure, central venous pressure and oxygen saturation monitoring during the whole procedure. All elements of the procedures involving manoeuvres in the cardiovascular system were performed under fluoroscopy [3, 4]. Electrodes were dissected by means of an electric knife and their lumen was engaged with a standard guidewire. An attempt to unscrew the fixing element in case of active fixation electrodes was performed under fluoroscopy. If it was possible to use manual traction, an electrode stabilized with a guidewire covered with long sheath from the electrode extraction set was used. In all other cases a countertraction technique was applied. It is based on the use of a locking stylet (Liberator, COOK) and telescope Teflon or polypropylene sheaths (7-16 F). In case of failure to release the electrode from its adhesions, especially on its course in the subclavian or innominate vein, with the use of Teflon or polypropylene sheaths, mechanical traction by means of the COOK evolution set was applied. This technique was described in detail previously [5-8]. After removal of an unnecessary electrode the remaining sheath from the electrode extraction set was used to introduce a hemodynamic guidewire $(0.8 \mathrm{~mm}, 150 \mathrm{~cm}$ length) into the right atrium. In situations where implantation of more than 1 electrode was needed an adequate number of guidewires was introduced. After removal of the extraction sheath the introduced guidewires were covered in a typical way with vas-

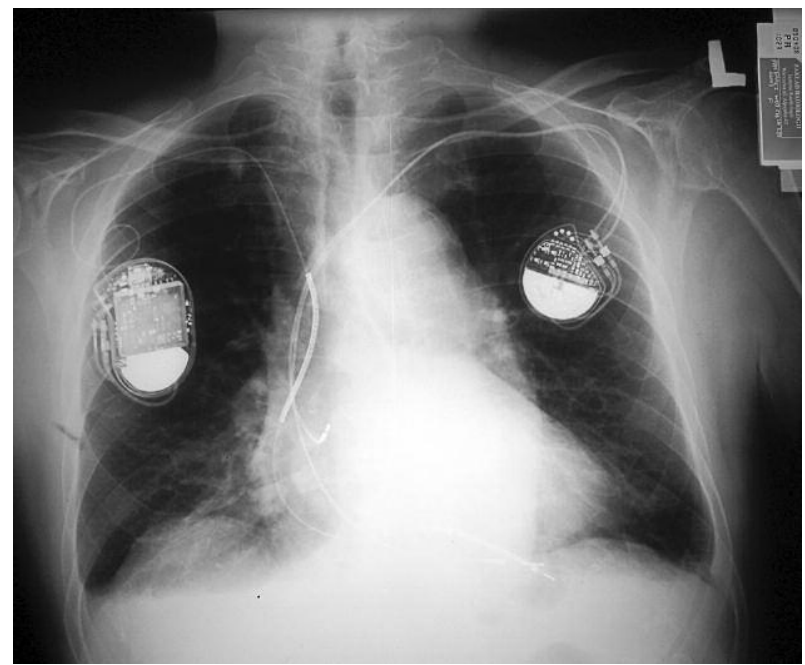

Fig. 3. DDD type pacemaker implanted on the left side (electrodes are placed in the right atrium and in the right ventricle). During observation it was necessary to install an ICD, which was implanted on the right side due to left subclavian vein occlusion (antero-posterior view)

Ryc. 3. Stan po implantacji układu stymulującego typu DDD po stronie lewej (elektrody umieszczone w prawym przedsionku i prawej komorze). W czasie dalszej obserwacji pojawity się wskazania do implantacji ICD, który wszczepiono po stronie prawej z powodu niedrożności lewej żyły podobojczykowej (projekcja przednio-tylna) cular peel-away sheaths (8-10 F, depending on the type of electrode). They were subsequently used to introduce new electrodes into the venous system. Electrodes were implanted according to the current standards with radiological control of their position and measurement of electrophysiological parameters. Then electrodes were connected to the device, which was placed in the implantation site. The wound was sutured in layers. After the procedure patients remained under observation in the intensive care unit. All procedures of electrode extraction were followed by echocardiographic and radiological (exclusion of pulmonary emphysema) examination.

\section{Statistical analysis}

Continuous variables were presented as arithmetic means \pm standard deviations (SD) and categorical variables were depicted as percentages (\%).

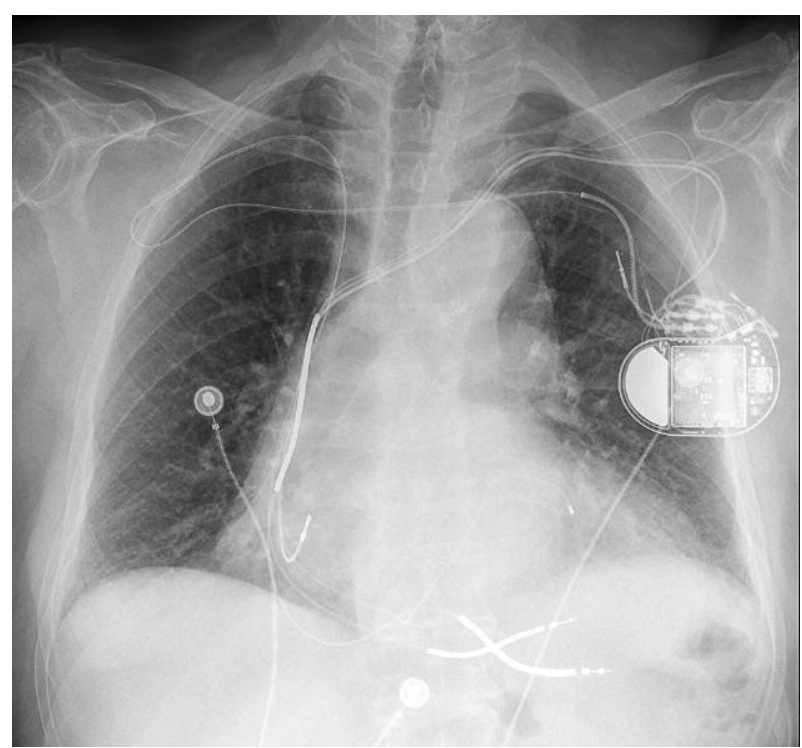

Fig. 4. CRT-D implanted on the left side. Visible electrodes: atrial, right ventricular (dual-coil type) and left ventricular. Damage to the right ventricular electrode was noted a few years after its implantation. It was impossible to implant a new electrode on the left side due to subclavian vein occlusion. Because of lack of patient's consent for removal of an old electrode, the new one was implanted on the right side and tunnelized subcutaneously to the site of CRT-D implantation

Ryc. 4. Stan po wszczepieniu układu CRT-D po stronie lewej. Widoczne elektrody: przedsionkowa, prawokomorowa (typu dual-coil) oraz lewokomorowa. Kilka lat po implantacji stwierdzono uszkodzenie elektrody prawokomorowej. Implantacja nowej elektrody po stronie lewej była niemożliwa ze względu na niedrożność żyły podobojczykowej. Z powodu braku zgody chorego na usunięcie starej elektrody wszczepiono nowa po stronie prawej i tunelizowano podskórnie do loży CRT-D 


\section{Results}

During the analysed period a necessity to restore the vascular access was the main indication for the procedure in 10 patients (4.9\%). The need for implantation of a new electrode was related to: (1) electrode damage -7 patients; (2) system upgrade (the use of resynchronization therapy) -3 patients.

Patients' clinical characteristics are presented in Table 1. Mean age of the patients was $59.5 \pm 21.4$ years (14-80 years). In 5 patients only one electrode was removed. In 5 other cases it was necessary to extract more than 1 electrode. This was caused by malfunction of another electrode $(n=2)$, presence of the pacemaker on the other side of the body $(n=1)$, and dislocation or damage of an electrode during the procedure $(n=2)$. Altogether, 23 electrodes were extracted (9 defibrillation electrodes, 12 pacing electrodes and 2 left ventricular electrodes). Mean time from their implantation was 92.2 \pm 42.21 months (48-152 months). In the case of 20 electrodes, Teflon or polypropylene sheaths were used. Additional application of the Evolution system (except telescopic sheaths) was necessary for the extraction of three electrodes [4]. Manual traction (after previous extraction of a different electrode and restoration of venous access by means of telescopic sheaths) was enough for removal of three electrodes. Previously implanted, correctly functioning atrial electrodes were left in two cases. Detailed data presenting types of extracted electrodes, their age and the applied technique are presented in Table 2 . In all cases it was possible to implant new electrodes as pre-planned. There were no serious complications in the analysed group (death, need for surgical intervention, pulmonary embolism, complications of anaesthesia, stroke or systemic infection).

\section{Discussion}

The study presented the management technique in case of venous occlusion in patients with previously implanted pacing or defibrillating electrodes, who require implantation of a new electrode. According to the current guidelines of the cardiological societies, class I indications for electrode extraction include bilateral subclavian vein or superior vena cava thrombosis in patients who require implantation of a new electrode. Class I indications also include situations when contralateral implantation is contraindicated (for example in patients after mastectomy or with the presence of a dialysis fistula). Restoration of venous access, if contralateral implantation is possible, was given a class II indication [3, 4]. There are not many studies on this subject in the literature [9-11]. It is difficult to assess in which percent of cases venous occlusion was the main indication for extraction of a previously implanted electrode. It is also impossible to find out how often alternative strategies are used (contralateral implantation or electrode tunnelization). There are also no data on the frequency of the use of other techniques for the system upgrade (for example, sewing of the left ventricular electrode with cardio-surgical methods) or how frequently the idea of system upgrade or the use of resynchronization therapy is abandoned. Venous occlusion is relatively frequent in patients with implanted endocavitary electrodes [1]. It is assumed that various degrees of stenosis are present in about $30 \%$ of patients. Due to asymptomatic course the diagnosis is made during system upgrade or removal of the damaged electrode. This has significant practical implications: venous patency on the side of the planned implantation should also be assessed before the procedure. Examinations shown to adequately assess the status of the venous sys-

Table 1. Clinical characteristics of patients

Tabela 1. Charakterystyka kliniczna chorych

\begin{tabular}{|c|c|c|c|c|c|c|c|}
\hline Patient & Age [years] & Sex & Diagnosis & NYHA class & Present device & New device & $\begin{array}{l}\text { The number of } \\
\text { extracted leads }\end{array}$ \\
\hline 1 & 74 & $M$ & DCM & $I I / I I I$ & CRT-P & CRT-P & 1 \\
\hline 2 & 62 & $\mathrm{~F}$ & DCM & III & $\begin{array}{l}\text { ICD-VR (right side), } \\
\text { DDD (left side) }\end{array}$ & CRT-D & 3 \\
\hline 3 & 14 & $M$ & LQTS & 1 & ICD-DR & ICD-DR & 2 \\
\hline 4 & 68 & $\mathrm{~F}$ & TBS & II & DDD & DDD & 2 \\
\hline 5 & 23 & $\mathrm{~F}$ & LQTS & I & ICD-VR & ICD-VR & 2 \\
\hline 6 & 61 & $\mathrm{~F}$ & DCM & III & CRT-D & CRT-D & 3 \\
\hline 7 & 78 & $M$ & ICM & III & CRT-D & CRT-D & 4 \\
\hline 8 & 80 & $M$ & ICM & III & ICD-VR & ICD-VR & 2 \\
\hline 9 & 65 & $\mathrm{~F}$ & $\mathrm{HCM}$ & II & DDD & DDD & 2 \\
\hline 10 & 70 & $M$ & CAD & III & ICD-DR & CRT-D & 2 \\
\hline
\end{tabular}

M-male, F-female, DCM - dilated cardiomyopathy, LQTS - long QT syndrome, TBS - tachycardia-bradycardia syndrome, ICM - ischemic cardiomyopathy, HCM - hypertrophic cardiomyopathy

M - mężczyzna, F- kobieta, DCM - kardiomiopatia rozstrzeniowa, LQTS - zespół wydłużonego QT, TBS - zespół tachycardia-bradykardia, ICM - kardiomiopatia niedokrwienna, HCM - kardiomiopatia przerostowa 
Table 2. Data regarding the type of extracted electrodes and the extraction technique

Tabela 2. Dane dotyczace typu elektrod i techniki ich ekstrakcji

\begin{tabular}{|c|c|c|c|c|c|c|c|c|c|}
\hline $\begin{array}{l}\text { Elect- } \\
\text { rode }\end{array}$ & $\begin{array}{l}\text { Age } \\
\text { of the } \\
\text { electrode } \\
\text { [months] }\end{array}$ & $\mathrm{A} / \mathrm{RV} / \mathrm{LV}$ & $\begin{array}{l}\text { Fixation } \\
\text { type }\end{array}$ & $\begin{array}{l}\text { Traction } \\
\text { type }\end{array}$ & $\begin{array}{l}\text { Mechanical } \\
\text { sheath }\end{array}$ & $\begin{array}{l}\text { Locking } \\
\text { stylet } \\
\text { guidewire } \\
\text { (Liberator) }\end{array}$ & $\begin{array}{c}\text { Mechanical } \\
\text { sheath with } \\
\text { rotational tip } \\
\text { (Evolution) }\end{array}$ & $\begin{array}{l}\text { Complete } \\
\text { /partial } \\
\text { removal }\end{array}$ & $\begin{array}{l}\text { Time } \\
\text { of fluoro- } \\
\text { scopy } \\
\text { [min] }\end{array}$ \\
\hline 1 & 97 & RV & Active & Mechanical & 1 & 0 & 0 & Complete & 4 \\
\hline 2 & 152 & $A$ & Passive & Mechanical & 1 & 1 & 0 & Complete & 10 \\
\hline 3 & 152 & $\mathrm{RV}$ & Passive & Mechanical & 1 & 1 & 0 & Complete & 10 \\
\hline 4 & 46 & RV (ICD, two coils) & Active & Mechanical & 1 & 1 & 0 & Complete & 4 \\
\hline 5 & 48 & A & Active & Mechanical & 1 & 1 & 0 & Complete & 10 \\
\hline 6 & 48 & RV (ICD, two coils) & Active & Mechanical & 1 & 1 & 1 & Partial (7 cm left) & ft) 50 \\
\hline 7 & 60 & $A$ & Passive & Mechanical & 1 & 1 & 1 & Complete & 15.5 \\
\hline 8 & 60 & RV & Passive & Manual & 0 & 0 & 0 & Complete & 0.5 \\
\hline 9 & 75 & RV (ICD, single coil) & Active & Mechanical & 1 & 1 & 0 & Complete & 7.5 \\
\hline 10 & 51 & RV (ICD, two coils) & Passive & Mechanical & 1 & 1 & 0 & Complete & 10 \\
\hline 11 & 57 & A & Active & Manual & 0 & 0 & 0 & Complete & 5 \\
\hline 12 & 57 & RV (ICD, two coils) & Active & Mechanical & 1 & 1 & 0 & Complete & 10 \\
\hline 13 & 57 & LV & Passive & Mechanical & 1 & 0 & 0 & Complete & 7 \\
\hline 14 & 88 & $A$ & Passive & Mechanical & 1 & 1 & 0 & Complete & 8 \\
\hline 15 & 88 & RV & Passive & Mechanical & 1 & 1 & 0 & Complete & 5 \\
\hline 16 & 69 & RV (ICD, two coils) & Active & Mechanical & 1 & 0 & 0 & Complete & 10 \\
\hline 17 & 69 & LV & Passive & Mechanical & 1 & 0 & 0 & Complete & 2 \\
\hline 18 & 144 & RV (ICD, single coil) & Passive & Mechanical & 1 & 0 & 0 & Complete & 8 \\
\hline 19 & 83 & RV (ICD, single coil) & Active & Mechanical & 1 & 1 & 0 & Complete & 12 \\
\hline 20 & 164 & $A$ & Passive & Mechanical & 1 & 1 & 0 & Complete & 10 \\
\hline 21 & 164 & RV & Passive & Mechanical & 1 & 1 & 1 & Complete & 25 \\
\hline 22 & 146 & RV (ICD single coil) & Passive & Mechanical & 1 & 1 & 0 & Complete & 10 \\
\hline 23 & 146 & RA & Active & Mechanical & 1 & 1 & 0 & Complete & 3 \\
\hline
\end{tabular}

$A$ - atrial, $R V$ - right ventricular, $L V$ - left ventricular, ICD - implantable cardioverter-defibrillator

A - elektroda przedsionkowa, RV - elektroda prawokomorowa, LV - elektroda lewokomorowa, ICD - implantowany kardiowerter-defibrylator

tem include venography and computed tomography. Ultrasonography does not permit one to assess the patency of the innominate vein or superior vena cava. It is important to remember that contrast administration through the antecubital vein may not demonstrate stenosis or occlusion of the superior vena cava. One of the methods of assessment consists of subclavian vein puncture and an attempt to introduce a 0.32-0.35 F guidewire to the right atrium (before preparation of the implantation site). Continuation of the procedure depends on the possibility to overcome the eventual occlusion and to introduce the guidewire beyond the occlusion site. Detection of the venous occlusion permits one to avoid unnecessary preparation of the implantation site, which is related to patient discomfort and increased risk of infection. It also allows one to plan another management strategy. Several laser techniques used to remove old electrodes and regain venous access have been described in the literature [9]. It was possible to restore venous access for implan- tation of new electrodes in all cases of 18 patients undergoing this type of procedure. An interesting, but rather controversial technique was described by Staniforth and Schilling [11]. It is based on removal of metallic parts of the electrode from the isolation followed by the introduction of a hemodynamic guidewire inside the isolation and electrode removal through the femoral vein. The guidewire remains in the right atrium, which permits the installation of a new sheath and electrode introduction. It should be noted that in almost $10 \%$ of cases (a total of 34 patients) it was impossible to fully remove the electrode. Released electrodes left in the vascular system are a source of potential complications related to electrode migration, arrhythmia generation or pulmonary embolism. In conclusion, it should be noted that implantation of a new electrode on the side of the previously installed device is possible despite venous occlusion. It should be expected that the number of patients with indications for this type of procedure will continue to grow. Such treatment, how- 
ever, should be carried out with full cardio-surgical support, as the risk of serious complications associated with removal of the electrodes is $2-3 \%$. It should also be noted that venous access restored after removal of the electrode is usually not permanent and that clinical signs of venous thrombosis occur quite often, which may be associated with endothelial damage in a large portion of the vein and with closure of collateral circulation [12].

\section{Conclusions}

The presence of venous occlusion should not be regarded as a contraindication to an upgrade of the existing system or to implantation of new electrodes on the side of the previously implanted device. Transvenous techniques of electrode removal permit venous access to be restored.

\section{References}

1. Rozmus G, Daubert JP, Huang DT, et al. Venous thrombosis and stenosis after implantation of pacemakers and defibrillators. J Interv Card Electrophysiol 2005; 13: 9-19.

2. Bracke F, Meijer A, Van Gelder B. Venous occlusion of the access vein in patients referred for lead extraction: influence of patient and lead characteristics. Pacing Clin Electrophysiol 2003; 26: 1649-1652.

3. Mitkowski P. Nowe zalecenia Heart Rhytm Society dotyczące usuwania elektrod. W dobrym rytmie 2010. www.wdobrymrytmie.pl

4. Wilkoff BL, Love CJ, Byrd CL, et al. Transvenous lead extraction: Heart Rhythm Society expert consensus on facilities, training, indications, and patient management: this document was endorsed by the American Heart Association (AHA). Heart Rhythm 2009; 6: 1085-1104.

5. Kutarski A, Małecka B, Ruciński P, Ząbek A. Percutaneous extraction of endocardial leads - a single centre experience in 120 patients. Kardiol Pol 2009; 67: 149-156.

6. Kennergren C, Bjurman C, Wiklund R, Gäbel J. A single-centre experience of over one thousand lead extractions. Europace 2009; 11: 612-617.

7. Bongiorni MG, Soldati E, Zucchelli G, et al. Transvenous removal of pacing and implantable cardiac defibrillating leads using single sheath mechanical dilatation and multiple venous approaches: high success rate and safety in more than 2000 leads. Eur Heart J 2008; 29: 2886-2893.

8. Przybylski A, Syska P, Oręziak A, et al. Usefulness of the Evolution mechanical dilator sheath for endocardial lead extraction - preliminary results. Postep Kardiol Inter 2010; 6: 59-65.

9. Gula LJ, Ames A, Woodburn A, et al. Central venous occlusion is not an obstacle to device upgrade with the assistance of laser extraction. Pacing Clin Electrophysiol 2005; 28: 661-666.

10. Małecka B, Zabek A, Kutarski A, et al. Necessity of endocardial lead removal in device upgrade in a patient with left subclavian vein occlusion - a case report. Kardiol Pol 2009; 67: 451-454.

11. Staniforth AD, Schilling RJ. Reuse of occluded veins during permanent pacemaker lead extraction: a new indication for femoral lead extraction. Indian Pacing Electrophysiol J 2002; 2: 97-103.

12. Bracke FA, Meijer A, Van Gelder LM. Symptomatic occlusion of the access vein after pacemaker or ICD lead extraction. Heart 2003; 89: 1348-1349. 